\title{
Purification and characterization of $\mathrm{NAD}^{+}$:ADP-ribosyltransferase (polymerizing) from Dictyostelium discoideum
}

\author{
Barbara KOFLER, ${ }^{\star}$ Eva WALLRAFF, $\dagger$ Herbert HERZOG, ${ }^{\star} \ddagger$ Rainer SCHNEIDER, ${ }^{\star}$ Bernhard AUER ${ }^{\star}$ and Manfred SCHWEIGER ${ }^{\star} \|$ \\ *Institut für Biochemie (Nat. Fak.), Universität Innsbruck, A-6020 Innsbruch, Austria, and †Max-Planck-Institut für Biochemie, D-8033 Martinsried, Germany
}

\begin{abstract}
A novel affinity-purification scheme based on the tight binding of $\mathrm{NAD}^{+}$:ADP-ribosyltransferase (polymerizing) [pADPRT; poly(ADP-ribose) polymerase; EC 2.4.2.30] to single-strand nicks in DNA, single-stranded patches and DNA ends has been developed to facilitate the purification of this enzyme from the lower eukaryote Dictyostelium discoideum. Two homogeneous forms of the enzyme, with $M_{\mathrm{r}}$ values of 116000 and 90000 , were prepared from $D$. discoideum by using poly (A) hybridized to
\end{abstract}

oligo(dT)-cellulose as affinity material. The $K_{\mathrm{m}}$ is $20 \mu \mathrm{M} \mathrm{NAD}^{+}$ for the $90000-M_{\mathrm{r}}$ protein and $77 \mu \mathrm{M} \mathrm{NAD}^{+}$for the $116000-M_{\mathrm{r}}$ protein. The optimum conditions for the enzyme activity in vitro are $6-10^{\circ} \mathrm{C}$ and $\mathrm{pH} 8$. The time course is linear during the first $10 \mathrm{~min}$ of the reaction only. As in enzymes of higher eukaryotes, the activity is dependent on DNA and histone $\mathrm{Hl}$ and is inhibited by 3-methoxybenzamide, nicotinamide, theophylline, caffeine and thymidine.

\section{INTRODUCTION}

$\mathrm{NAD}^{+}$:ADP-ribosyltransferase (polymerizing) [pADPRT; poly(ADP-ribose) polymerase; EC 2.4.2.30], is an enzyme localized in the nucleus of eukaryotic cells. It catalyses the transfer of the ADP-ribose moiety from $\mathrm{NAD}^{+}$to proteins and finally forms branched poly(ADP-ribose) chains. This polymer is bound to various nuclear proteins which are involved in DNA metabolism and chromosomal architecture (De Murcia et al., 1988; Althaus et al., 1991). Inhibitor studies have shown that pADPRT plays a role in regulating cell proliferation (Colon-Otero et al., 1987; Kaiser et al., 1992), cell differentiation (Exley et al., 1987; McNerney et al., 1989; Williams et al., 1989; Cesarone et al., 1990; Golderer and Gröbner, 1990) and DNA repair (Shall, 1984; Schweiger et al., 1987; Satoh and Lindahl, 1992). Nevertheless, the ultimate answer to the question of what role pADPRT plays in the various cellular processes has not yet been found. Detection of loss-of-function mutants could possibly clarify this question. However, no mutants of this type have been found in higher eukaryotic systems so far. Negative mutants can be generated with the help of several techniques, such as the introduction of a highly expressed mutant pADPRT gene with a dominant negative function in cultured cells (Küpper et al., 1990). An alternative would be to inactivate the pADPRT gene by means of homologous recombination; however, the mouse is the only mammal in which this is possible. All these techniques are much more easily performed in lower-eukaryotic model systems; in addition, their extensive genetic background is also of advantage. Precise knowledge of the properties and characteristics of pADPRT and its gene in lower eukaryotes is a prerequisite for studies on pADPRT function in these organisms.

Saccharomyces cerevisiae, the lower eukaryote most widely used in cell proliferation, differentiation and DNA-repair studies, proved to be inappropriate, because ADP-ribosylation activity could not be detected in this organism (Scovassi et al., 1986; Kaiser et al., 1992). However, the slime mould Dictyostelium discoideum was found to contain pADPRT (Rickwood and Osman, 1979; Rickwood, 1982) and has also proved to be a useful model for studying cellular differentiation. The great advantage is that synchronous differentiation into two types of cells only can be induced in large numbers of these cells. Therefore D. discoideum was chosen to study the role of poly-ADPribosylation in the differentiation of cells, which is important for understanding the physiological function of this enzyme.

Unlike pADPRT from higher eukaryotes, pADPRT from $D$. discoideum and other lower eukaryotes could not be purified by affinity chromatography on 3-aminobenzamide-Sepharose (Burtscher et al., 1986, 1987a,b; Ushiro et al., 1987); therefore we have developed a novel purification scheme. Purified pADPRT was found to require DNA for its activity, which is a result of the enzyme's binding to strand breaks, nicks or singlestrand patches (Benjamin and Gill, 1980). On the basis of this property, poly(A)-oligo(dT)-cellulose was employed as an affinity matrix for pADPRT chromatography. Purification and characterization of pADPRT from $D$. discoideum by this method is described in the present study.

\section{MATERIALS AND METHODS}

\section{Materials}

Hydroxyapatite was synthesized by the method of Bernardi (1971). DEAE-cellulose and phosphocellulose (P11) were purchased from Whatman Biosystems (Maidstone, Kent, U.K.). Oligo(dT)-cellulose and poly(A) were from Boehringer Mannheim (Mannheim, Germany). Glass-fibre and nitrocellulose filters were obtained from Schleicher and Schüll (Dassel, Germany). Rainbow protein molecular-mass markers were purchased from Amersham International (Amersham, Bucks., U.K.); $\left[{ }^{32} \mathrm{P}\right] \mathrm{NAD}^{+}$and $\left[\right.$adenine $\left.-2,8-{ }^{3} \mathrm{H}\right] \mathrm{NAD}^{+}$were from $\mathrm{Du}$ Pont-New England Nuclear (Boston, MA, U.S.A.). 3Methoxybenzamide was obtained from Aldrich Chemical Co. (Milwaukee, WI, U.S.A.). Salmon protamine sulphate (grade I), phenylmethanesulphonyl fluoride, unlabelled $\beta-\mathrm{NAD}^{+}, \alpha-\mathrm{NAD}^{+}$, calf thymus DNA type I, histone $\mathrm{H} 1$ type $\mathrm{V}-\mathrm{S}$ from calf thymus, thymidine, caffeine, theophylline, theobromine, Coomassie Blue G-250, Coomassie Blue R-250, 5-bromo-4-chloro-3-indolyl 
phosphate and Nitro Blue Tetrazolium were purchased from Sigma Chemical Co. (St. Louis, MO, U.S.A.). Alkaline phosphatase-labelled affinity-purified pig anti-(goat IgG) antibodies were from Tago Inc. (Burlingame, CA, U.S.A.). All other chemicals were obtained from E. Merck (Darmstadt, Germany) and were of analytical grade. The inhibitors, 1,5-dihydroxy-4phthalazione, 3-aminophthalhydrazide, 3-guanidinobenzamide and 3-hydroxybenzamide were kindly given by Professor S. Shall of the University of Sussex.

\section{Enzyme assay}

pADPRT activity was assayed essentially as described previously by Burtscher et al. (1986), except that the reaction was carried out at $6^{\circ} \mathrm{C}$ for $10 \mathrm{~min}$.

\section{Protein determination}

Protein concentrations were determined by the Coomassie Blue G-250 dye-binding assay (Bradford, 1976), with BSA as the standard.

\section{PAGE}

SDS/polyacrylamide $(10 \%)$ slab gels were used and electrophoresis was performed by the method of Laemmli (1970). The gels were stained with Coomassie Blue R-250.

\section{Activity gel analysis}

Basically, this analysis was carried out as originally described by Scovassi et al. (1984) and modified by Burtscher et al. (1987a), except that the gel was incubated in $5 \mathrm{ml}$ of reaction mixture $\left\{100 \mathrm{mM}\right.$ Tris/ $\mathrm{HCl}, \mathrm{pH} 8,10 \mathrm{mM} \mathrm{MgCl}_{2}, 1 \mathrm{mM}$ dithiothreitol, $1 \mu \mathrm{M} \mathrm{NAD}{ }^{+}, 10 \mu \mathrm{Ci} / \mathrm{ml}\left[{ }^{32} \mathrm{P}^{2} \mathrm{NAD}^{+}(800 \mathrm{Ci} / \mathrm{mmol} ; 5 \mathrm{mCi} / \mathrm{ml}\}\right.$ at $6^{\circ} \mathrm{C}$ for $12 \mathrm{~h}$.

\section{Immunoblotting}

Samples of the two affinity-purified forms of pADPRT eluted together at $100 \mathrm{mM} \mathrm{KCl}$ were separated by SDS/PAGE $(10 \%$ gel) and transferred to a nitrocellulose membrane [wet blot; $3 \mathrm{~g} / 1$ Tris $/ \mathrm{HCl}, 14.4 \mathrm{~g} / \mathrm{l}$ glycine, $0.02 \%$ SDS, $20 \%$ (v/v) methanol; $50-60 \mathrm{~V}, 2-4 \mathrm{~h}]$. The further procedures were performed as described by Schneider et al. (1987).

\section{Protein purfication}

Cultivation of cells

Ax-2 wild-type amoebae were grown in an axenic culture at $27^{\circ} \mathrm{C}$ (Watts and Ashworth, 1970). Instead of glucose, maltose $(18 \mathrm{~g} / \mathrm{l})$ was used as a carbon source in the medium. The cells were harvested by centrifugation at $700 \mathrm{~g}$ for $10 \mathrm{~min}$ and then washed by suspension in phosphate-buffered saline and subsequent re-centrifugation. The following procedures were all carried out at $4^{\circ} \mathrm{C}$.

\section{Crude extract}

The washed cell pellet $(120 \mathrm{~g})$ was homogenized by sonication in $360 \mathrm{ml}$ of buffer A, pH 7.3 [50 mM Tris/ $\mathrm{HCl}, 25 \mathrm{mM} \mathrm{K}_{2} \mathrm{~S}_{2} \mathrm{O}_{5}$, $12 \mathrm{mM} \beta$-mercaptoethanol, $1 \mathrm{mM}$ phenylmethanesulphonyl fluoride, $20 \%(\mathrm{v} / \mathrm{v})$ glycerol] containing $0.5 \mathrm{M}-\mathrm{KCl}$.

\section{Protamine sulphate precipitation}

$96 \mathrm{ml}$ of a $1 \%(\mathrm{w} / \mathrm{v})$ protamine sulphate solution was added slowly by stirring the homogenate for $20 \mathrm{~min}$ (the final con- centration of protamine sulphate was $0.2 \%$ ). The homogenate was centrifuged at $16000 \mathrm{~g}$ for $20 \mathrm{~min}$.

\section{Hydroxyapatite I}

The supernatant was shaken with $120 \mathrm{~g}$ of hydroxyapatite

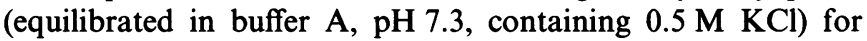
$60 \mathrm{~min}$. The suspension was centrifuged at $1600 \mathrm{~g}$ for $5 \mathrm{~min}$. Then the supernatant was discarded, and the hydroxyapatite pellet was washed with $2 \times 300 \mathrm{ml}$ of buffer A, pH 7.3, containing $0.5 \mathrm{M} \mathrm{KCl}$. Elution was carried out by shaking the hydroxyapatite in $3 \times 100 \mathrm{ml}$ of buffer $\mathrm{A}, \mathrm{pH} 7.3$, containing $0.5 \mathrm{M}$ $\mathrm{KH}_{2} \mathrm{PO}_{4}$ for $20 \mathrm{~min}$. It was then centrifuged as described above.

\section{DEAE-cellulose}

The combined hydroxyapatite I eluates were diluted 5-fold with buffer A, pH 8, and filtered through $200 \mathrm{ml}$ of DEAE-cellulose (equilibrated with buffer $\mathrm{A}, \mathrm{pH} 8$ ) settled in a Buchner funnel (10 $\mathrm{cm}$ in diameter).

Phosphocellulose (P11)

The filtrate of the DEAE-cellulose was diluted with buffer A, $\mathrm{pH} 7.3$, until a conductivity of $5 \mathrm{mS}$ was achieved, and filtered through a Buchner funnel containing $100 \mathrm{ml}$ of settled phosphocellulose which had been precycled and equilibrated with buffer

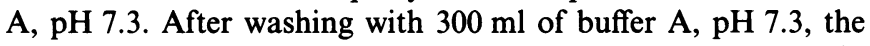
phosphocellulose pellet was packed into a column $(5 \mathrm{~cm}$ in diameter). Subsequently a linear gradient of $0-0.5 \mathrm{M} \mathrm{KCl}$ in buffer A was applied.

\section{Hydroxyapatite II}

Active fractions which started to be eluted at $6 \mathrm{mS}$ were pooled and incubated with $10 \mathrm{~g}$ of hydroxyapatite. After shaking the suspension for $30 \mathrm{~min}$, the hydroxyapatite was washed with $2 \times 100 \mathrm{ml}$ of buffer $\mathrm{A}, \mathrm{pH} 7.3$, containing $2.5 \mathrm{M} \mathrm{KCl}$ and once with $50 \mathrm{ml}$ of pure buffer $\mathrm{A}, \mathrm{pH}$ 7.3. The hydroxyapatite was eluted with $3 \times 10 \mathrm{ml}$ of buffer $\mathrm{A}, \mathrm{pH} 7.3$, containing $0.5 \mathrm{M}$ $\mathrm{KH}_{2} \mathrm{PO}_{4}$. The pooled eluates were dialysed extensively against buffer B (50 mM Tris/ $\mathrm{HCl}, \mathrm{pH} 8.0,0.5 \mathrm{mM}$ EDTA, $12 \mathrm{mM} \beta$ mercaptoethanol, $5 \mathrm{mM} \mathrm{MgCl}, 25 \mathrm{mM} \mathrm{K} \mathrm{K}_{2} \mathrm{~S}_{2} \mathrm{O}_{5}, 1 \mathrm{mM}$ phenylmethanesulphonyl fluoride, $5 \%$ glycerol).

\section{Poly(A)-oligo(dT)-cellulose}

The dialysed solution was applied to the affinity column $(2 \mathrm{ml}$, equilibrated with buffer B). After washing the column with $20 \mathrm{ml}$ of buffer $\mathrm{B}$, the enzymes were eluted stepwise with $50 \mathrm{mM}$ and $100 \mathrm{mM} \mathrm{KCl}$ in buffer $\mathrm{B}$.

\section{Preparation of the affinity column}

Oligo(dT)-cellulose $(1 \mathrm{~g})$ was suspended in $10 \mathrm{ml}$ of buffer $B$ containing $1 \mathrm{M} \mathrm{KCl}$ for $10 \mathrm{~min}$. A solution of poly(A) $(10 \mathrm{mg} / \mathrm{ml}$ in $10 \mathrm{mM}$ Tris $/ \mathrm{HCl}, \mathrm{pH} 8.0,1 \mathrm{mM}$ EDTA) was incubated with the oligo(dT)-cellulose suspension [ $100 A_{260}$ units/g of dry powder oligo(dT)-cellulose] by shaking it at room temperature for $30 \mathrm{~min}$. After equilibration of the affinity material with buffer B, the amount of bound poly(A) was estimated by measuring the decrease in u.v. absorption $(260 \mathrm{~nm})$ of the supernatant.

\section{Catalytic properties}

Enzyme kinetics

Samples $(10 \mu \mathrm{l})$ of the purified enzymes were added to $90 \mu \mathrm{l}$ of the reaction mixture containing different concentrations of 
unlabelled $\mathrm{NAD}^{+}$(final concns.: $100,75,50,25,10$ and $1 \mu \mathrm{M}$ ) and incubated at $6^{\circ} \mathrm{C}$ for $10 \mathrm{~min}$.

\section{Temperature optimum}

Enzyme solution $(10 \mu \mathrm{l})$ was added to $90 \mu \mathrm{l}$ of prewarmed/ precooled reaction mixture and incubated at $0,6,10,15,20,25$ or $37^{\circ} \mathrm{C}$ for $10 \mathrm{~min}$. The reaction was stopped by adding $100 \mu \mathrm{l}$ of $40 \%(w / v)$ trichloroacetic acid.

\section{Time course}

The reaction mixture and enzyme solution were cooled to $6^{\circ} \mathrm{C}$, mixed together and, after incubation for $0,1,2,4,6,8,10,15$, $20,25,30,40,60$ or $120 \mathrm{~min}, 100 \mu \mathrm{l}$ portions were added to $100 \mu \mathrm{l}$ of $40 \%$ trichloroacetic acid.

\section{DNA and histone $\mathrm{H} 1$ dependence}

Reaction mixture $(90 \mu \mathrm{l})$ with or without DNA $(20 \mu \mathrm{g} / \mathrm{ml})$ and histone H1 $(20 \mu \mathrm{g} / \mathrm{ml})$ were incubated with $10 \mu \mathrm{l}$ of enzyme solution at $6^{\circ} \mathrm{C}$ for $10 \mathrm{~min}$. The activity was determined as described above.

Inhibitors

Stock solutions ( 1 or $10 \mathrm{mM}$ ) of nicotinamide, thymidine, caffeine, 3-hydroxybenzamide, 3-guanidinobenzamide, theophylline and 3-aminophthalhydrazide were prepared in water. Methanolic stock solutions $(10 \mathrm{mM})$ of 1,5-dihydroxy-4phthalazione and 3-methoxybenzamide were diluted. A $10 \mu \mathrm{l}$ portion of an inhibitor of appropriate dilution (final concn. $1 \mathrm{mM}-0.1 \mu \mathrm{M}$ ) were mixed with $10 \mu \mathrm{l}$ of enzyme solution and subsequently added to $80 \mu \mathrm{l}$ of reaction mixture. The activity assay was performed as described above.

\section{Analysis of ADP-ribose polymers}

The size of the pADPRT reaction product was determined on non-denaturing polyacrylamide gels (Panzeter and Althaus, 1990 ; Simonin et al., 1991). Protein solution $(50 \mu \mathrm{l})$ was incubated with $450 \mu$ l of reaction mixture $\{100 \mathrm{mM}$ Tris $/ \mathrm{HCl}, \mathrm{pH} 8,1 \mathrm{mM}$ dithiothreitol, $20 \mu \mathrm{g} / \mathrm{ml}$ activated DNA (Loeb, 1969), $20 \mu \mathrm{g} / \mathrm{ml}$ histone $\mathrm{Hl}, 2 \mu \mathrm{l}$ of $\left.{ }^{32} \mathrm{P}^{2} \mathrm{NAD}^{+}(800 \mathrm{Ci} / \mathrm{mmol} ; 5 \mathrm{mCi} / \mathrm{ml})\right\}$ at $6^{\circ} \mathrm{C}$ for $30 \mathrm{~min}$. The reaction product was precipitated with $500 \mu \mathrm{l}$ of $40 \%$ trichloroacetic acid at $0^{\circ} \mathrm{C}$ for $2 \mathrm{~h}$. After centrifugation, the pellet was washed with $2 \times 1 \mathrm{ml}$ of $1 \%$ trichloroacetic acid and once with $1 \mathrm{ml}$ of methanol, diethyl ether $(1: 1, v / v)$. The dried pellet was dissolved in $200 \mu 1$ of $10 \mathrm{mM}$ Tris/ $\mathrm{HCl}\left(\mathrm{pH} \mathrm{12)} / 1 \mathrm{mM}\right.$ EDTA and incubated at $60^{\circ} \mathrm{C}$ for $2 \mathrm{~h}$. The samples were extracted once with water-saturated phenol/ chloroform $(1: 1, \mathrm{v} / \mathrm{v})$ and evaporated in a vacuum desiccator. The pellets were dissolved in $10 \mu \mathrm{l}$ of water and $10 \mu \mathrm{l}$ of stop mixture [ $50 \%$ (w/v) urea, $25 \mathrm{mM} \mathrm{NaCl}, 4 \mathrm{mM}$ EDTA, $\mathrm{pH} 7.5$, $0.02 \%$ xylene cyanole FF, $0.02 \%$ Bromophenol Blue]. Then the samples were loaded on to a $20 \%$-acrylamide gel $[19.86 \%$ acrylamide $/ 0.24 \%$ bisacrylamide $(\mathrm{w} / \mathrm{w})$, in $0.09 \mathrm{M}$ Tris $/ \mathrm{HCl}$ (pH 8.3)/0.09 M boric acid/2 mM EDTA] and electrophoresis was carried out at a constant power of $55 \mathrm{~W}$. The gel was dried and the polymers were made visible by autoradiography.

\section{RESULTS}

\section{Purfification of $D$. discoideum pADPRT}

Standard enzyme purification from about $120 \mathrm{~g}$ of cells resulted in $0.1 \mathrm{mg}$ of a 1700 -fold enriched enzyme preparation. The data from a representative procedure are summarized in Table 1 . The first steps are, with slight modifications, the same as those described by Burtscher et al. (1986). A crude extract of $D$. discoideum cells was prepared by sonication, and then the DNA was removed by protamine sulphate precipitation. The supernatant was mixed in one batch with hydroxyapatite, which was washed and eluted with $0.5 \mathrm{M} \mathrm{KH}_{2} \mathrm{PO}_{4}$. The eluate was diluted and filtered through a DEAE-cellulose column to remove residual DNA, which would interfere with the binding of the enzyme to the chromatography materials used in subsequent steps. Then the filtrate was again diluted and loaded on to a phosphocellulose column, to which a linear gradient of $0-0.5 \mathrm{M} \mathrm{KCl}$ was applied. The active fractions, which started to be eluted at $6 \mathrm{mS}$, were pooled (Figure 1, lane 1) and treated again with hydroxyapatite. At this stage it was possible to wash the hydroxyapatite with $2.5 \mathrm{M} \mathrm{KCl}$ to remove most of the protein (Figure 1, lane 2). The elution was carried out as described above. Although at this stage the enzyme is strongly inhibited by 3-methoxybenzamide (see also Figure 6), all attempts to bind the $D$. discoideum pADPRT to 3-aminobenzamide-Sepharose failed.

As a final purification step, chromatography was performed on oligo(dT)-cellulose to which poly(A) was hybridized in a $1 \mathrm{M}$

Table 1 Purification of ADPRT from D. discoideum

\begin{tabular}{|c|c|c|c|c|}
\hline Step & $\begin{array}{l}\text { Total } \\
\text { protein } \\
\text { (mg) }\end{array}$ & $\begin{array}{l}\text { Specific } \\
\text { activity } \\
\text { (pmol/min } \\
\text { per } \mathrm{mg} \text { ) }\end{array}$ & $\begin{array}{l}\text { Purification } \\
\text { (fold) }\end{array}$ & $\begin{array}{l}\text { Recovery } \\
(\%)\end{array}$ \\
\hline Crude extract & 13000 & 0.42 & 1.0 & 100 \\
\hline Protamine sulphate & 6400 & 1.5 & 3.5 & 170 \\
\hline Hydroxyapatite I & 1300 & 5.5 & 13.1 & 130 \\
\hline DEAE-cellulose & 1200 & 13 & 31 & 286 \\
\hline Phosphocellulose & 78 & 23 & 55 & 33 \\
\hline Hydroxyapatite II & 27 & 35 & 84 & 17 \\
\hline Poly(A)-oligo(dT)-cellulose & 0.1 & 700 & 1700 & 1.3 \\
\hline
\end{tabular}

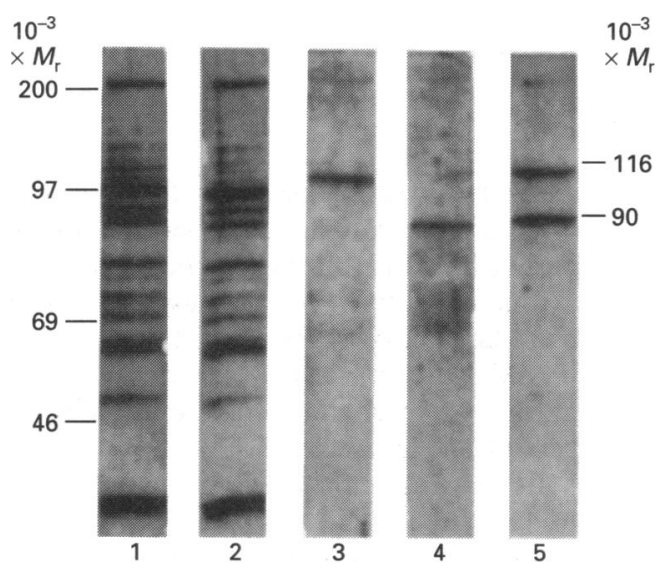

Figure 1 SDS/PAGE analysis of purification steps of PADPRT from D. discoideum

Lane 1, phosphocellulose pool; lane 2, hydroxyapatite II after dialysis; lanes 3-5, elution from poly(A)-oligo(dT)-column: with $50 \mathrm{mM} \mathrm{KCl}$ (lane 3); with $100 \mathrm{mM} \mathrm{KCl}$ after elution with $50 \mathrm{mM} \mathrm{KCl}$ (lane 4); directly eluted with $100 \mathrm{mM} \mathrm{KCl}$ (lane 5). Electrophoresis was carried out as described in the Materials and methods section. $M_{\mathrm{r}}$ markers were myosin $(200000)$, phosphorylase $b(97000)$, BSA (69000) and ovalbumin (46000). 


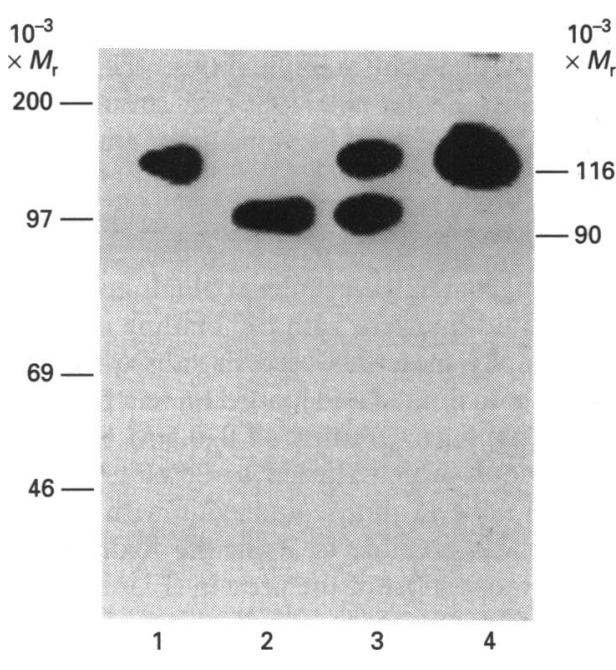

Figure 2 Activity-gel analysis of purtiled pADPRT

The protein solutions were run on SDS/PAGE (10\% gel), re-activated and incubated with $\left.{ }^{32} \mathrm{P}\right] N A D^{+}$, and the active bands were detected by autoradiography. Lanes $1-3$, purified PADPRT from $D$. discoideum: $750 \mathrm{ng}$ of protein after elution from poly(A)oligo(dT)-cellulose column with $50 \mathrm{mM} \mathrm{KCl}$ (lane 1); $750 \mathrm{ng}$ of protein eluted with $100 \mathrm{mM}$ $\mathrm{KCl}$ after elution with $50 \mathrm{mM} \mathrm{KCl}$ (lane 2); $1.5 \mu \mathrm{g}$ of protein directly eluted with $100 \mathrm{mM} \mathrm{KCl}$ (lane 3); lane 4, purified human PADPRT $(50 \mathrm{ng}) . M_{\mathrm{r}}$ markers were as for Figure 1.

Table 2 Histone and DNA requirements for $116000-M_{r}$ and $90000-M_{r}$ PADPRTs from $D$. discoideum

For assay conditions see the Materials and methods section.

\begin{tabular}{llll}
\hline & \multicolumn{3}{c}{ Activity $(\%)$} \\
\cline { 3 - 4 } $\begin{array}{lll}\text { Histone } \\
(20 \mu \mathrm{g} / \mathrm{ml})\end{array}$ & DNA & $\begin{array}{l}116000-M_{\mathrm{r}} \\
\text { protein }\end{array}$ & $\begin{array}{l}90000-M_{\mathrm{r}} \\
\text { protein }\end{array}$ \\
\hline+ & & & \\
+ & + & 100 & 100 \\
+ & + & 24.0 & 23 \\
- & - & 10.1 & 5 \\
& - & 7.3 & 5.6 \\
\hline
\end{tabular}

$\mathrm{KCl}$ buffer. The active hydroxyapatite fractions were dialysed and applied to the affinity column. Elution with $100 \mathrm{mM} \mathrm{KCl}$ yielded a fraction with a 1700 -fold-enriched enzyme activity; $1.3 \%$ of the enzyme activity in the crude extract was recovered (Table 1; Figure 1, lane 5). As shown by Coomassie Blue R-250 staining after PAGE (Figure 1), stepwise elution with $50 \mathrm{mM}$ $\mathrm{KCl}$ and $100 \mathrm{mM} \mathrm{KCl}$ resulted in the isolation of an active protein of $M_{\mathrm{r}} 116000$ (Figure 1, lane 3) and a second active protein of $M_{\mathrm{r}} 90000$ (Figure 1, lane 4). Activity-gel analysis (Figure 2) showed that equal amounts of either protein produced signals of the same intensity (Figure 2, lane 3).

\section{Characterization of the enzyme}

The purified enzymes require DNAase I-treated DNA for optimum activity. In the presence of DNA the enzymes can be further stimulated 5-fold by addition of histone $\mathrm{H} 1$ (Table 2). Without activated DNA, however, the enzyme activity is decreased to $5 \%$ of the maximum even if histone $\mathrm{H} 1$ is added.
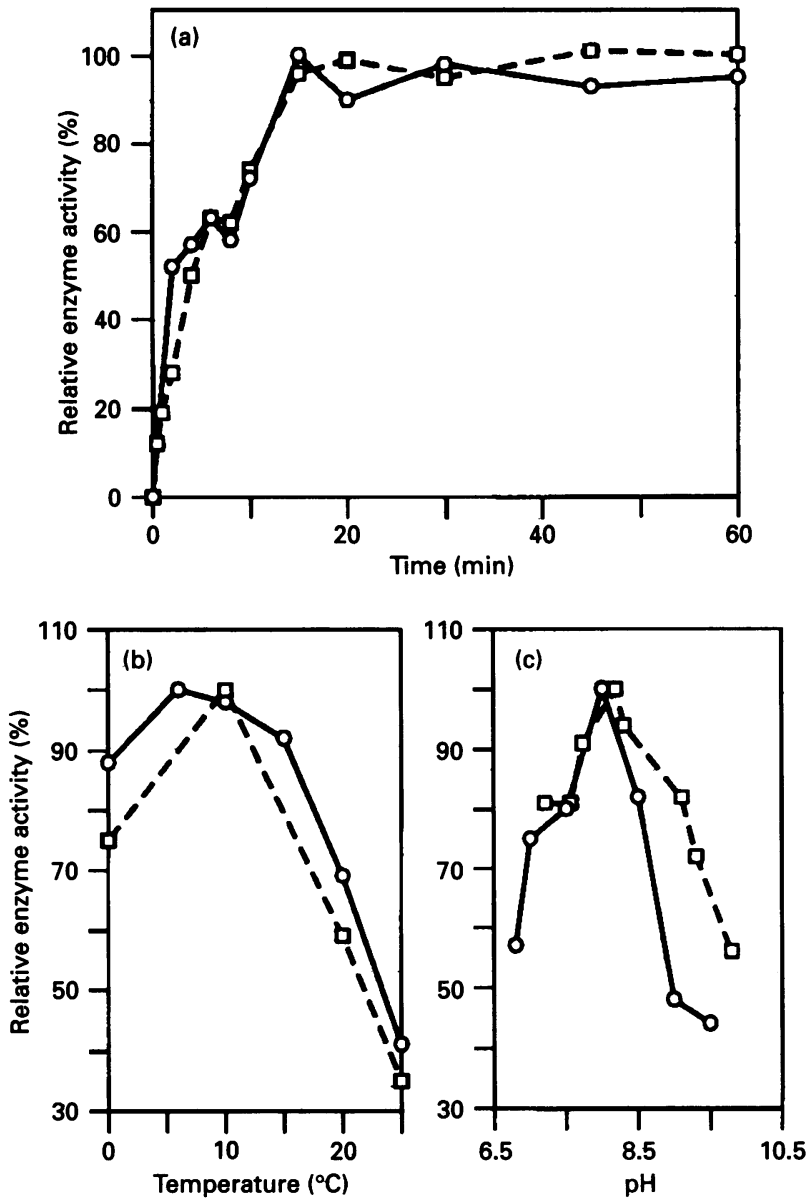

Figure 3 Properties of purfilied pADPRTs from $D$. discoideum

Enzyme: $\bigcirc, 116000-M_{r} ; \square, 90000-M_{r}$. (a) Time course during the enzyme reaction; (b) temperature-dependence; (c) $\mathrm{pH}$ optimum. The experimental conditions are described in the Materials and methods section.

The time course of the enzyme activities of the two proteins is linear during the first $10 \mathrm{~min}$ only. After $12 \mathrm{~min}$ the activity gradually levels off, and after $\mathbf{2 0}$ min there is no further increase in acid-precipitable radioactivity (Figure 3a). The optimum temperature is $6-10^{\circ} \mathrm{C}$ for both enzymes (Figure $3 b$ ).

In the presence of histone $\mathrm{Hl}$ and DNA the $\mathrm{pH}$ optimum, at pH 8 (Figure 3c), is rather narrow. pH changes by 1 unit in either direction decreased the enzyme activity by about $20 \%$. Analysis of ADP-ribose polymers produced in vitro by a sequencing gel showed chains of length up to 50 ADP-ribose units (Figure 4). There was no difference in length between the poly(ADP-ribose) chains produced by human pADPRT and those originating from D. discoideum enzymes (Figure 4).

\section{Kinetic constants}

Lineweaver-Burk analysis of enzyme kinetics revealed different Michaelis-Menten constants for both enzymes. The $90000-M_{\mathrm{r}}$ species showed a $K_{\mathrm{m}}$ of $20 \pm 2 \mu \mathrm{M} \mathrm{NAD}^{+}$, whereas the $K_{\mathrm{m}}$ of the $116000-M_{\mathrm{r}}$ protein was $77 \pm 1 \mu \mathrm{M} \mathrm{NAD}^{+}$under optimum conditions (Figure 5). pADPRT from $D$. discoideum was found to be sensitive to several $\mathrm{NAD}^{+}$competitors, such as 1,5-dihydroxy-4phthalazione, 3-methoxybenzamide (Figure 6), 3-aminophthalhydrazide, 3-guanidinobenzamide and nicotinamide, used at concentrations of 0.1-100 $\mu \mathrm{M}$. 3-Hydroxybenzamide, $\alpha-\mathrm{NAD}^{+}$, 


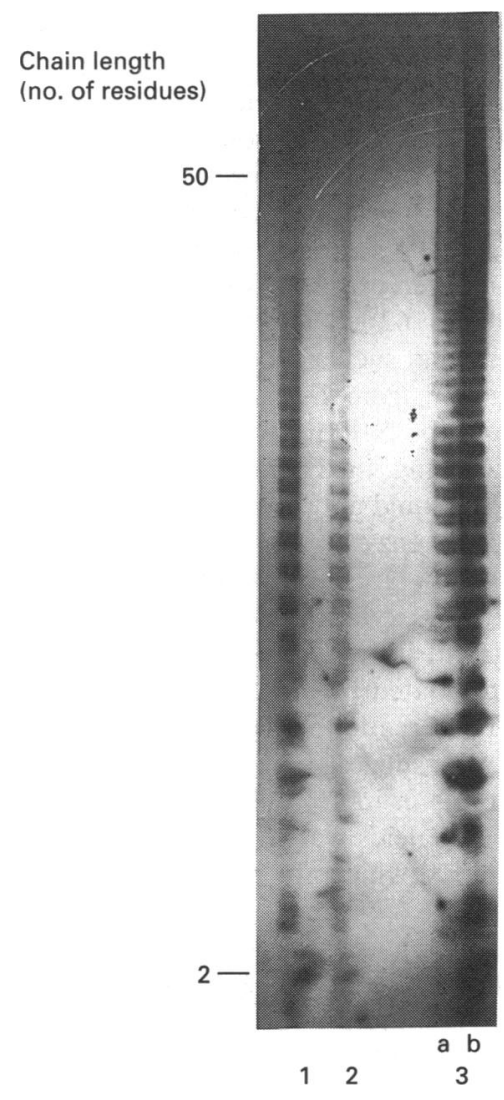

Figure 4 Analysis of the reaction product from PADPRT

PADPRT was incubated with $100 \mu \mathrm{M} \mathrm{NAD}+$ and $5 \mu \mathrm{Ci}$ of [ $\left.{ }^{32} \mathrm{P}\right] \mathrm{NAD}^{+}$. The labelled reaction product was precipitated, washed and detached from proteins. The polymers of ADP-ribose were loaded on to a $20 \%$ non-denaturing sequencing gel. Lane 1 , crude extract from $D$. discoideum $(10 \mu \mathrm{g})$; lane 2, purified $116000-M_{\mathrm{r}}$ protein from $D$. discoideum $(100 \mathrm{ng})$; lanes $3 \mathrm{a}, 3 \mathrm{~b}$, purified human PADPRT (a, $1 \mathrm{ng} ; \mathrm{b}, 10 \mathrm{ng}$ ).

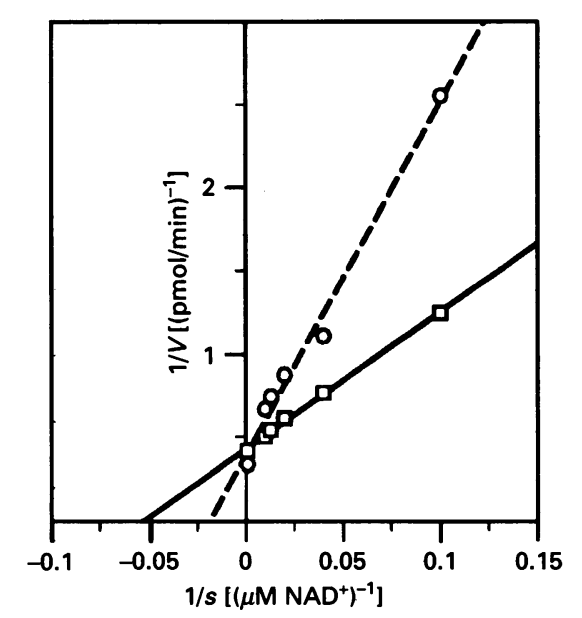

\section{Figure 5 Lineweaver-Burk plots of pADPRT reaction}

Purified enzyme preparations $\left(O, 116000-M_{r} ; \square, 90000-M_{r}\right)$ were incubated under standard reaction conditions as described in the Materials and methods section, except that the concentration of $\mathrm{NAD}^{+}$was varied as specified above. The data from a representative experiment are depicted. The $K_{\mathrm{m}}$ values of both enzyme classes were calculated as the mean of two experiments with four replicates for each concentration $\left(77 \pm 1 \mu \mathrm{M} \mathrm{NAD}{ }^{+}\right.$for $116000-M_{r^{\prime}}$ $20 \pm 2 \mu \mathrm{M} \mathrm{NAD}^{+}$for $90000-M_{\mathrm{r}}$ ).

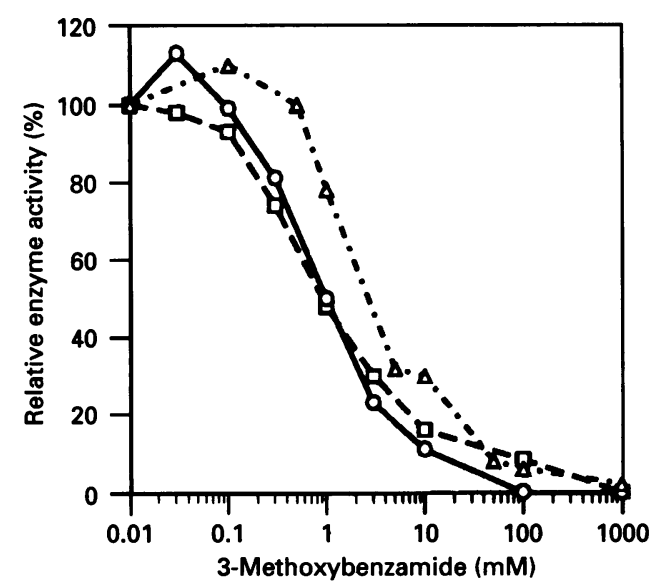

Figure 6 Inhibition of the activity of PADPRT from $D$. discoideum by 3-methoxybenzamide

Purified enzyme preparations $\left(O, 116000-M_{r} ; \square, 90000-M_{r} ; \triangle, 116000-M_{r}\right.$ human PADPRT) were incubated with various concentrations of 3-methoxybenzamide in standard assay mixture as described in the Materials and methods section.

Table 3 Effect of pADPRT inhibltors on $116000-M_{r}$ and $90000-M$, pADPRTs from $\mathbf{D}$. discoideum

Inhibitors were added to the standard enzyme assay at the concentrations described in the Materials and methods section. Abbreviation: n.d., not determined.

\begin{tabular}{|c|c|c|c|}
\hline \multirow[b]{2}{*}{ Inhibitor } & \multirow[b]{2}{*}{ Concn. } & \multicolumn{2}{|l|}{ Activity (\%) } \\
\hline & & $\begin{array}{l}116000-M_{r} \\
\text { protein }\end{array}$ & $\begin{array}{l}90000-M_{\mathrm{r}} \\
\text { protein }\end{array}$ \\
\hline Control & - & 100 & 100 \\
\hline \multirow[t]{3}{*}{ 3-Methoxybenzamide } & $1 \mathrm{mM}$ & 2 & 0 \\
\hline & $10 \mu \mathrm{M}$ & 15 & 16 \\
\hline & $1 \mu \mathrm{M}$ & 50 & 48 \\
\hline \multirow[t]{3}{*}{ Nicotinamide } & $1 \mathrm{mM}$ & 4 & 5 \\
\hline & $100 \mu \mathrm{M}$ & 28 & 25 \\
\hline & $10 \mu \mathrm{M}$ & n.d. & 63 \\
\hline \multirow[t]{3}{*}{ 3-Hydroxybenzamide } & $100 \mu \mathrm{M}$ & 11 & n.d. \\
\hline & $10 \mu \mathrm{M}$ & 64 & n.d. \\
\hline & $1 \mu \mathrm{M}$ & 82 & n.d. \\
\hline \multirow[t]{3}{*}{ 3-Guanidinobenzamide } & $100 \mu \mathrm{M}$ & 29 & n.d. \\
\hline & $10 \mu \mathrm{M}$ & 86 & n.d. \\
\hline & $1 \mu \mathrm{M}$ & 98 & n.d. \\
\hline \multirow[t]{3}{*}{ 3-Aminophthalhydrazide } & $100 \mu \mathrm{M}$ & 2 & n.d. \\
\hline & $10 \mu \mathrm{M}$ & 12 & n.d. \\
\hline & $1 \mu \mathrm{M}$ & 53 & n.d. \\
\hline \multirow[t]{3}{*}{ 1,5-Dihydroxy-4-phthalazione } & $10 \mu \mathrm{M}$ & 0 & n.d. \\
\hline & $1 \mu \mathrm{M}$ & 5 & n.d. \\
\hline & $0.1 \mu \mathrm{M}$ & 64 & n.d. \\
\hline \multirow[t]{2}{*}{$\alpha-N^{+} D^{+}$} & $500 \mu \mathrm{M}$ & 60 & 56 \\
\hline & $100 \mu \mathrm{M}$ & n.d. & 76 \\
\hline Thymidine & $1 \mathrm{mM}$ & 6 & 12 \\
\hline Theophylline & $1 \mathrm{mM}$ & 32 & 61 \\
\hline Caffeine & $1 \mathrm{mM}$ & 14 & 43 \\
\hline $\mathrm{KCl}$ & $100 \mathrm{mM}$ & n.d. & 15 \\
\hline
\end{tabular}

thymidine, caffeine and theophylline also inhibited both enzymes (Table 3). Like the $116000-M_{\mathrm{r}}$ pADPRT from human tissue, the $116000-M_{\mathrm{r}}$ enzyme from $D$. discoideum was significantly stimulated by concentrations as low as $50 \mathrm{nM}$ 3-methoxybenzamide (Jones et al., 1988). Three independent experiments with four 
replicates each revealed an increase to $114 \pm 4.58 \%$ (mean \pm S.D.) of the activity of the untreated enzyme. Interestingly, the 90000 $M_{\mathrm{r}}$ protein $(99.3 \pm 1.15 \%$; mean \pm S.D. $)$ was found to be unable to be activated by very low concentrations of inhibitor.

\section{DISCUSSION}

pADPRTs from several higher eukaryotes were purified to homogeneity by affinity chromatography on 3-aminobenzamideSepharose (Burtscher et al., 1986, 1987a,b; Ushiro et al., 1987). Unlike pADPRT from higher species, pADPRT from $D$. discoideum did not bind to the immobilized form of 3-methoxybenzamide, although both enzymes were inhibited by the same concentration of this compound. Therefore, we have made use of the DNA-binding property of pADPRT in an attempt to develop an effective purification scheme. pADPRT was found to bind strongly to double-stranded DNA containing a variety of strand breaks, by which it is activated. However, single-stranded DNA as well as poly $(\mathrm{dA})$ and poly(dT) homopolymers proved to be ineffective inductors. As expected, pADPRT did not bind to oligo(dT)-cellulose. On the other hand, poly $(\mathrm{dA})$ is very effective in activating pADPRT, if it is hybridized to poly(dT) (Benjamin and Gill, 1980). Therefore, we used poly(A) hybridized to oligo(dT)-cellulose for the purification of pADPRT by affinity chromatography. In contrast with all other proteins from the active fractions yielded by phosphocellulose chromatography, pADPRTs from $D$. discoideum and human placenta (results not shown) bound tightly to this affinity matrix. Stepwise elution resulted in the separation of two homogeneous active pADPRT proteins with $M_{\mathrm{r}}$ values of 116000 and 90000 . This indicates a somewhat increased affinity of the shorter pADPRT species for poly(A)-oligo(dT)-cellulose and demonstrates its efficiency as an affinity-chromatography support for pADPRT purification.

The high recovery rate of $286 \%$ observed during the first steps of the purification scheme may be due to the removal of an inhibitor, probably $D$. discoideum DNA. Similar rates have been reported for the human and the trout enzyme (Carter and Berger, 1982; Burtscher et al., 1987b). During the subsequent purification steps the enzyme is rather unstable, resulting in an overall yield of $1.3 \%$ and a considerable loss of activity due to freezing and thawing of the enzyme solution. The maximum activity of the enzyme is observed at $6-10^{\circ} \mathrm{C}$, which is $10-15^{\circ} \mathrm{C}$ below the optimum temperature for culturing $D$. discoideum. This was found to be a common feature of pADPRTs in all species examined (Althaus and Richter, 1987). The temperature optimum for the purified active proteins is somewhat lower than the optimum required for the enzyme activity in nuclei of $D$. discoideum (Rickwood and Osman, 1979). Conversely, the $\mathrm{pH}$ optimum in the alkaline region is the same as in nuclei (Rickwood and Osman, 1979) and is similar to that found in other species (Ito et al., 1979; Burtscher et al., 1987a,b; Golderer et al., 1988). Product analysis demonstrated that the polymeric products obtained from the purified $116000-M_{\mathrm{r}}$ enzyme in vitro are identical in length with those synthesized from the purified human enzyme. Despite these similarities in enzyme properties between pADPRT from $D$. discoideum and human pADPRT, immunoblot analysis using antibodies against the purified human enzyme shows no cross-reaction with the two forms of pADPRT from $D$. discoideum. This is in agreement with the results obtained when using antibodies against calf thymus pADPRT, which react with the extracts of several higher eukaryotes, but not with those of lower eukaryotes (Scovassi et al., 1986).

Although the purification scheme was optimized with regard to time $(32 \mathrm{~h})$ and proteolytic degradation (phenylmethane- sulphonyl fluoride, $\mathrm{K}_{2} \mathrm{~S}_{2} \mathrm{O}_{5}$ ), the appearance of the $90000-M_{\mathrm{r}}$ protein could not be prevented. Nevertheless, when the serine protease inhibitor phenylmethanesulphonyl fluoride was added, the yield of the $116000-M_{\mathrm{r}}$ protein increased significantly as compared with the $90000-M_{\mathrm{r}}$ species (results not shown). This indicates that a specific proteolytic processing step may exist in $D$. discoideum, similar to that described for the human enzyme, which results in different pADPRT fragments, with $M_{r}$ values of 96000, 79000 and 62000-60000 (Surowy and Berger, 1983, $1985)$. Assuming that such a processing step exists, the $90000-M_{\mathrm{r}}$ pADPRT fragment from $D$. discoideum would lack 200 amino acids either from the $\mathrm{N}$-terminal or from the $\mathrm{C}$-terminal end. If the latter were lacking, the $\mathrm{NAD}^{+}$-binding domain would be lost and the fragment would not show any enzyme activity, supposing the $D$. discoideum enzyme and the various pADPRT species analysed up to now are homologous. Regarding the inhibitor kinetics of 3-methoxybenzamide (Figure 6), the $90000-M_{r}$ pADPRT fragment from $D$. discoideum appears to have lost the ability to be stimulated by low doses of inhibitor. This may be due to loss of interaction between multiple binding sites for $\mathrm{NAD}^{+}$, which were suggested to cause activation of $\mathrm{pADPRT}$ at low concentrations of inhibitors (Jones et al., 1988).

If the 200 amino acids were cleaved from the $\mathrm{N}$-terminal end, the two zinc fingers, which are supposed to represent the DNAbinding domain (Kameshita et al., 1986; Gradwohl et al., 1990) would be lost, and binding to poly(A)-oligo(dT)-cellulose would not occur. In fact, the $90000-M_{\mathrm{r}}$ protein binds to poly(A)-oligo(dT)-cellulose more strongly than the $116000-M_{r}$ species. In human pADPRT there is probably a unique sequence motif, located at the amino acids 207-213 and 346-352, which specifically recognizes the DNA ligand and can therefore replace the function of the two zinc fingers (Kurosaki et al., 1987). Interestingly enough, the $90000-M_{\mathrm{r}}$ pADPRT from $D$. discoideum is also activated by damaged DNA, as was previously shown for the $75000-M_{\mathrm{r}}$ pADPRTs from Helix pomatia and trout (Burtscher et al., 1987a,b). Moreover, the $K_{\mathrm{m}}\left(20 \mu \mathrm{M} \mathrm{NAD}^{+}\right)$of the $90000-M_{\mathrm{r}}$ pADPRT from $D$. discoideum was found to be in the same range as the $K_{\mathrm{m}}(26 \mu \mathrm{M}$ and $24 \mu \mathrm{M}$ respectively) of the 75000- $M_{\mathrm{r}}$ enzymes from Helix pomatia and trout (Burtscher et al., 1987a,b). The values are in agreement with the $K_{\mathrm{m}}(18 \mu \mathrm{M}$ $\mathrm{NAD}^{+}$) reported for pADPRT from $D$. discoideum nuclei (Rickwood and Osman, 1979). The $K_{\mathrm{m}}$ of the $116000-M_{\mathrm{r}}$ enzyme from $D$. discoideum (77 $\mu \mathrm{M} \mathrm{NAD}^{+}$), however, was slightly higher than the respective values found for purified $116000-M_{\mathrm{r}}$ enzymes from human ( $52 \mu \mathrm{M}$, Burtscher et al., 1986;61.7 $\mu \mathrm{M}$, Ushiro et al., 1987) and calf thymus pADPRTs (55 $\mu \mathrm{M}$; Ito et al., 1979).

An answer to these discrepancies may be found by analysing the structure of the $D$. discoideum pADPRT gene. However, purification of a sufficient amount of the enzyme by the procedure described in the present study is a prerequisite for this endeavour, which will also provide new insights into the evolution of pADPRT and its functional domains.

This study was supported by grant $9182 \mathrm{~B}$ of the Austrian Ministry of Science and Research.

\section{REFERENCES}

Althaus, F. R. and Richter, C. (1987) in ADP-Ribosylation of Proteins, Enzymology and Biological Significance (Solioz, M., ed.), pp. 1-122, Springer Verlag, Berlin and Heidelberg

Althaus, F. R., Bachmann, S., Braun, S. A., Collinge, M. A., Höfferer, L., Malanga, M., Panzeter, P. L., Realini, C., Richard, M. C., Waser, S. and Zweifel, B. (1991) in ADPRibosylation Reactions (Poirier, G. G. and Moreau, P., eds.), pp. 355-361, Springer Verlag, New York

Benjamin, R. C. and Gill, D. M. (1980) J. Biol. Chem. 255, 10502-10508 
Bernardi, G. (1971) Methods Enzymol. 22, 325-339

Bradford, M. M. (1976) Anal. Biochem. 72, 248-254

Burtscher, H. J., Auer, B., Klocker, H., Schweiger, M. and Hirsch-Kauffmann, M. (1986) Anal. Biochem. 152, 285-290

Burtscher, H. J., Klocker, H., Schneider, R., Auer, B., Hirsch-Kauffmann, M. and Schweiger, M. (1987a) Biochem. J. 248, 859-864

Burtscher, H. J., Schneider, R., Klocker, H., Auer, B., Hirsch-Kauffmann, M. and Schweiger, M. (1987b) J. Comp. Physiol. B 157, 567-572

Carter, S. G. and Berger, N. A. (1982) Biochemistry 21, 5475-5481

Cesarone, C. F., Scarabelli, L., Scovassi, A. I., Izzo, R., Menegazzi, M., Carcereri De Prati,

A., Orunesu, M. and Bertazzoni, U. (1990) Biochim. Biophys. Acta 108, 241-246

Colon-0tero, G., Sando, J. J., Sims, J. L., McGrath, E., Jensen, D. E. and Quesenberry, P. J. (1987) Blood 70, 686-693

De Murcia, G., Huletsky, A. and Poirier, G. (1988) Biochem. Cell Biol. 66, 626-635

Exley, R., Gordon, J. and Clemens, M. M. (1987) Proc. Natl. Acad. Sci. U.S.A. 84, $6467-6470$

Golderer, G. and Gröbner, P. (1990) Differentiation 45, 7-13

Golderer, G., Schneider, R., Auer, B., Loidl, P. and Gröbner, P. (1988) Biochem. J. 253, 859-867

Gradwohl, G., Menissier-de Murcia, J., Molinete, M., Simonin, F., Koken, M., Hoeijmakers,

J. H. J. and de Murcia, G. (1990) Proc. Natl. Acad. Sci. U.S.A. 87, 2990-2994

Ito, S., Shizuta, Y. and Hayashi, O. (1979) J. Biol. Chem. 254, 3647-3651

Jones, J., Patel, B. N. and Skidmore, C. J. (1988) Carcinogenesis 9, 2023-2026

Kaiser, P., Auer, B. and Schweiger, M. (1992) Mol. Gen. Genet. 232, 231-239

Kameshita, I., Matsuda, M., Nishikimi, M., Ushiro, H. and Shizuta, Y. (1986) J. Biol. Chem. 261, 3863-3868

Küpper, H. J., de Murcia, G. and Bürkle, A. (1990) J. Biol. Chem. 265, 18721-18724
Kurosaki, T., Ushiro, H., Mitsuuchi, Y., Suzuki, S., Matsuda, M., Matsuda, Y., Katunuma, N., Kangawa, K., Matsuo, H., Hirose, T., Inayama, S. and Shizuta, Y. (1987) J. Biol. Chem. 262, 15990-15997

Laemmli, U. K. (1970) Nature (London) 227, 680-685

Loeb, L. A. (1969) J. Biol. Chem. 244, 1672-1681

McNerney, R., Tavasolli, M., Shall, S., Brazinski, A. and Johnstone, A. (1989) Biochim. Biophys. Acta 1009, 185-187

Panzeter, P. L. and Althaus, F. R. (1990) Nucleic Acids Res. 18, 2194

Rickwood, D. (1982) in ADP-Ribosylation Reactions (Hayaishi, O. and Ueda, K., eds.), pp. 253-261, Academic Press, New York

Rickwood, D. and Osman, M. S. (1979) Mol. Cell. Biochem. 27, 79-84

Satoh, M. S. and Lindahl, T. (1992) Nature (London) 356, 356-358

Schneider, R., Auer, B., Kühne, C., Herzog, H., Klocker, H., Burtscher, H. J., HirschKauffmann, M., Wintersberger, U. and Schweiger, M. (1987) Eur. J. Cell Biol. 44 302-307

Schweiger, M., Auer, B., Burtscher, H. J., Hirsch-Kauffmann, M., Klocker, H. and Schneider, R. (1987) Eur. J. Biochem. 165, 235-242

Scovassi, I. A., Stefanini, M. and Bertazzoni, U. (1984) J. Biol. Chem. 259, 10973-10977

Scovassi, I. A., Izzo, R., Franchi, E. and Bertazzoni, U. (1986) Eur. J. Biochem. 159, 77-84 Shall, S. (1984) Adv. Radiat. Biol. 11, 1-69

Simonin, F., Briand, J., Muller, S. and de Murcia, G. (1991) Anal. Biochem. 195, 226-231

Surowy, C. S. and Berger, N. A. (1983) J. Biol. Chem. 258, 579-583

Surowy, C. S. and Berger, N. A. (1985) Biochim. Biophys. Acta 832, 33-45

Ushiro, H., Yokoyama, Y. and Shizuta, Y. (1987) J. Biol. Chem. 262, 2352-2357

Watts, D. J. and Ashworth, J. M. (1970) Biochem. J. 119, 171-174

Williams, G. T., Taylor, D. R., Jenkinson, E. J., Gritfin, E. and Hill, M. E. (1989) in ADPRibose Transfer Reactions: Mechanisms and Biological Significance (Jacobson, M. K. and Jacobson, E. L., eds.), pp. 310-315, Springer Verlag, New York

Received 14 September 1992/29 January 1993; accepted 8 February 1993 